\title{
Transcriptional and Physiological Responses to Nutrient Loading on Toxin Formation and Photosynthesis in Microcystis Aeruginosa FACHB-905
}

\author{
Guotao Peng ${ }^{1,2, *}$, Sijie Lin ${ }^{2}$, Zhengqiu Fan ${ }^{1}$ and Xiangrong Wang ${ }^{1, *}$ \\ 1 Department of Environmental Science and Engineering, Fudan University, Shanghai 200433, China; \\ zhqfan@fudan.edu.cn \\ 2 College of Environmental Science and Engineering, State Key Laboratory of Pollution Control and \\ Resource Reuse, Tongji University, Shanghai 200092, China; lin.sijie@tongji.edu.cn \\ * Correspondence: gtpeng11@fudan.edu.cn (G.P.); xrxrwang@fudan.edu.cn (X.W.); \\ Tel.: +86-021-5566-4052 (G.P.); +86-021-6564-3343 (X.W.)
}

Academic Editor: Luis M. Botana.

Received: 6 April 2017; Accepted: 11 May 2017; Published: 17 May 2017

\begin{abstract}
An important goal of understanding harmful algae blooms is to determine how environmental factors affect the growth and toxin formation of toxin-producing species. In this study, we investigated the transcriptional responses of toxin formation gene $(m c y B)$ and key photosynthesis genes ( $p s a B, p s b D$ and $r b c L$ ) of Microcystis aeruginosa FACHB-905 in different nutrient loading conditions using real-time reverse transcription quantitative polymerase chain reaction (RT-qPCR). Three physio-biochemical parameters (malondialdehyde (MDA), superoxide dismutase (SOD) and glutathione (GSH)) were also evaluated to provide insight into the physiological responses of Microcystis cells. We observed an upregulation of $m c y B$ gene in nutrient-deficient conditions, especially in nitrogen $(\mathrm{N})$ limitation condition, and the transcript abundance declined after the nutrient were resupplied. Differently, high transcription levels were seen in phosphorus (P) deficient treatments for key photosynthesis genes throughout the culture period, while those in $\mathrm{N}$-deficient cells varied with time, suggesting an adaptive regulation of Microsystis cells to nutrient stress. Increased contents of antioxidant enzymes (SOD and GSH) were seen in both N and P-deficient conditions, suggesting the presence of excess amount of free radical generation caused by nutrient stress. The amount of SOD and GSH continued to increase even after the nutrient was reintroduced and a strong correlation was seen between the MDA and enzyme activities, indicating the robust effort of rebalancing the redox system in Microcystis cells. Based on these transcriptional and physiological responses of M. aeruginosa to nutrient loading, these results could provide more insight into Microcystis blooms management and toxin formation regulation.
\end{abstract}

Keywords: microcystin; mcy; antioxidant system; nitrogen; phosphorus

\section{Introduction}

Blooms of toxic cyanobacteria have become a global environmental problem and a threat to the aquatic ecosystem and human health [1,2]. Among different algal species, Microcystis is of great interest because of the release of a potent hepatotoxin, microcystin (MC) [1-4]. The environmental factors, including temperature, light density, inorganic carbon and nutrient that drive Microcystis bloom formation, biological community structure and toxin production have been extensively studied. Some reports also demonstrated the changes of growth and MC production in Microcystis aeruginosa affected by other cyanotoxins, such as cylindrospermopsin [5,6]. Among the limiting factors, the important roles of nitrogen $(\mathrm{N})$ and phosphorus $(\mathrm{P})$, including nutrient availability and chemical forms, have gained widespread attention in recent years [7-9]. 
Since most freshwater ecosystems are P-limited, P loading was thought to act as a limiting factor in promoting the cyanobacterial blooms for decades [10,11]. However, conflicting reports exist. Some laboratory studies indicated that the P-deficient condition did not have impact on the growth rate of Microcystis [12,13], while others have showed that the growth of the same species declined in a P-limited condition primarily on account of a low carbon fixation rate [14]. Moreover, the effect of $\mathrm{P}$ availability on toxin production of Microcystis has been widely discussed, but still remains controversial [15,16]. Utkilen and Gjølme [17] stated that P-deficient conditions had no influence on the toxin production of $M$. aeruginosa, but iron-deficient conditions did. Others stated that increases of the MC concentration per dry weight were found under more P-limited conditions [14,18]. More recently, Kuniyoshi et al. [13] found that under a N/P ratio of 40:1 (P-deficient), the $M$. aeruginosa cells displayed high levels of $m c y D$ transcript abundance along with intracellular MC content, which stressed the important role of N:P ratio in mcy transcription and MC production [15].

Besides $\mathrm{P}, \mathrm{N}$ may be considered as having an equally important role in the occurrence of toxic, non-fixing cyanobacteria blooms, such as Microcystis $[19,20]$. Several laboratory studies have shown that increase of nitrate availability triggers Microcystis growth [21,22]. However, an excess of nitrate might inhibit the cells growth and reduce the photosynthetic activity consequently [8]. A binding site for the universal nitrogen regulator protein NtcA has been identified in the mcy bidirectional promotor region [23], which has sparked a debate on the subject of whether the MC production would be upor down-regulated by the $\mathrm{N}$ availability. An increase of toxin amount was observed with increasing nitrate availability in M. aeruginosa [24,25], while opposite results have demonstrated an increase of MC production in N-limited conditions [26,27]. Sevilla et al. [21] reported that the MC concentration correlated with $m c y D$ gene transcript, but both of them were independent from nitrate availability.

In either P or $\mathrm{N}$ limitation condition, reactive oxygen species (ROS) are generated due to the existence of several cross-regulatory reactions in cells, like nutrient acquisition, photosynthesis and redox control [28]. Under normal condition, concentration of ROS remains low due to the presence of antioxidant enzymes in cells, including catalase, superoxide dismutase, ascorbate peroxides, and glutathione [29]. The activities of these enzymes might be significantly enhanced due to an excess amount of ROS induced by stress [30,31], which reflect the rebalance of the physiological properties of Microcystis and help to understand the biochemical and molecular reactions in cells.

Numerous studies have been conducted to evaluate the effects of nutrient on the growth and biosynthesis of MC in Microcystis [15,26]. However, results are diversified and the cellular mechanism trigging the toxin production remains unclear. In light of the aforementioned conflicting reports, the aim of this study was to examine effects of nutrient loading on $M$. aeruginosa in terms of transcriptional and physiological responses. Target genes associated with toxin formation $(m c y B)$ and photosynthesis ( $p s a B, p s b D$ and $r b c L$ ) were selected, along with three physio-biochemical parameters (malondialdehyde (MDA), superoxide dismutase (SOD) and glutathione (GSH)) to address this question. It is worth noting that we resupplied the nutrient to cells after nutrient starvation for several days, which has not been investigated previously and would provide insight to the recovery growth of $M$. aeruginosa. The results of this work could contribute to the existing literature by offering new insights into the ecological importance of nutrient for cyanobacteria cell metabolism.

\section{Results}

\subsection{Cell Growth}

Cell abundance of $M$. aeruginosa was determined daily at each treatment (Figure 1). From the beginning of incubation, a significant decrease was seen in N-deficient treatments compared to control. After $\mathrm{N}$ was reintroduced on Day 5, the cell number turned to show a trend of increase but their growth was still significant lower than the control (Figure 1A). As for P treatments, a slight decrease was found in P-deficient group in the first three days but the cells presented a normal exponential growth from Day 4 (Figure 1B). No significant differences were seen between P-deficient cultures and 
the control on Day 5, although the maximum cell density was obtained in the control on Day 9. The cell density decreased after P was added on Day 5, but their number increased slightly later. Moreover, the number of cells under $\mathrm{N}$ treatments were significant lower than those of $\mathrm{P}$ treatments and control from Day 3, and the differences enhanced with the extension of the incubation time.

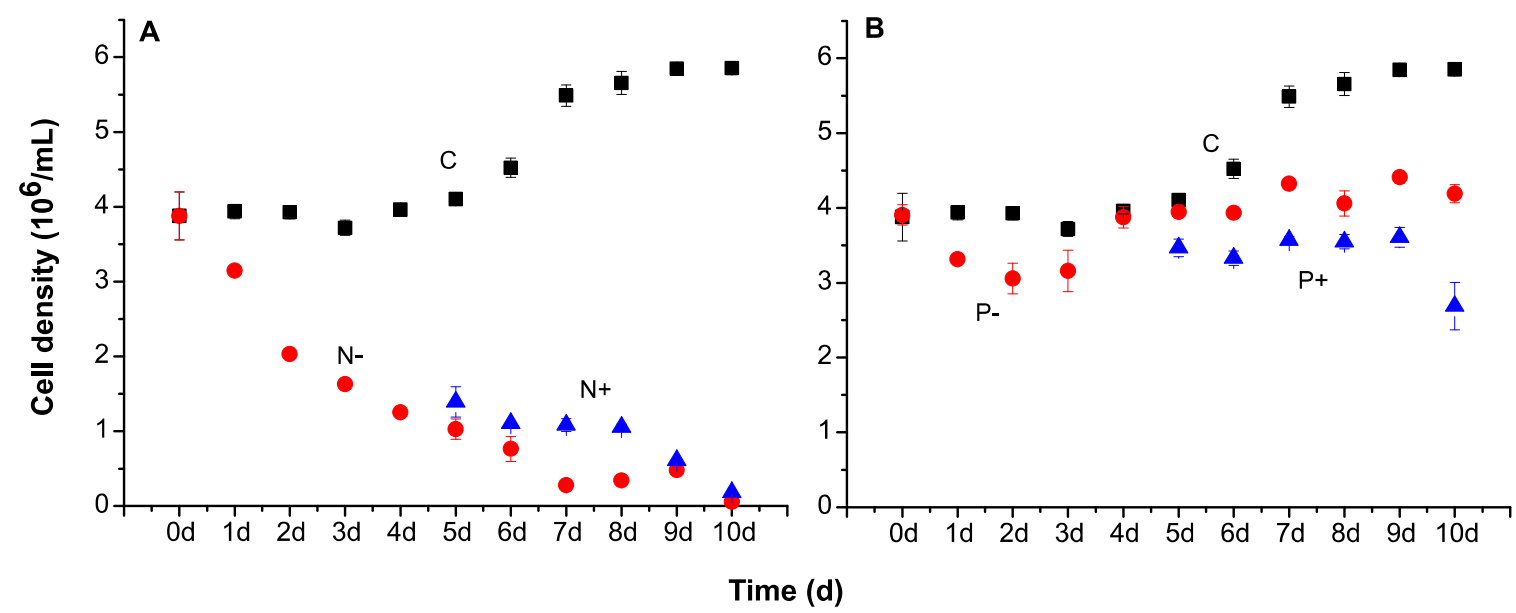

Figure 1. Cell density of M. aeruginosa at each treatment: nitrogen (A); and phosphorus (B). Different colors indicate different treatments: control (black), nutrient-deficient (red) and nutrient-added treatments (blue).

\subsection{RT-qPCR Assay Performance}

Transcripts of key genes associated with $\mathrm{MC}$ formation $(m c y B)$ and photosynthesis $(p s a B, p s b D$, $r b c L$ ) and were quantified via RT-qPCR (Figures 2 and 3). Transcripts number of mcyB showed a significant increase in $\mathrm{N}$-deficient treatments, about 3.5-fold higher than the control on Day 5, and the number increased markedly, reaching about 7.5-fold higher on Day 9. Interestingly, the expression of $m c y B$ gene dropped 3.8-fold after $\mathrm{N}$ was added (Figure 2). In contrast, no significant differences were found between P-deficient treatments and the control on Day 5. The transcripts of P-deficient cultures showed a rising trend lately, but the differences narrowed after $\mathrm{P}$ was added (Figure 3). Compared to the nutrient-deficient groups, significant declines were seen when $\mathrm{N}$ or $\mathrm{P}$ was added, especially in $\mathrm{N}$ treatments $(p<0.001)$.

In comparison, transcriptional profiles for the key photosynthesis genes were quite different to the $m c y B$ gene was seen. On Day 5, transcripts of all these three genes in N-deficient groups decreased significantly than the control. Different results were seen in P-deficient cultures. Apart from the significant decrease of $p s a B$ transcripts, the expression of the other two genes maintained at a high level $(r b c L)$ or ever higher ( $p s b D$, about 1.5-fold) than the control (Figures 2 and 3). More interestingly, the transcripts number increased dramatically in nutrient deficient groups and were significantly higher than the control on Day 9, except psaB gene in N-deficient cultures. After nutrient was supplied, no differences of $p s a B$ and $p s b D$ transcripts were seen in $\mathrm{N}$ and P-added treatments compared to the control, while the $r b c L$ gene transcripts in those cultures were still higher. When comparing the nutrient-deficient and nutrient-added treatments, significant results were seen only in $P$ treatments ( $p s a B$ and $p s b D)$. 

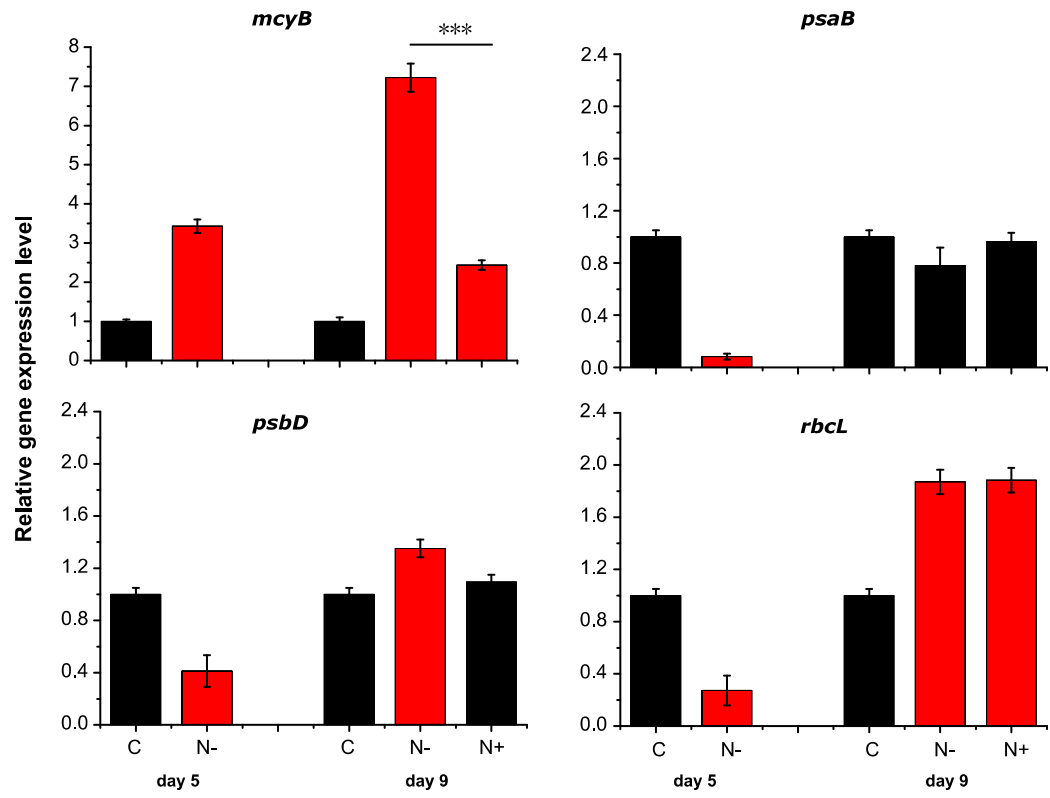

Treatment (N)

Figure 2. Relative transcription levels of target genes in $\mathrm{N}$ treatments. Red colors indicate the significant results compared to the control $(p<0.05)$. Significant differences are noted between $\mathrm{N}$-deficient and $\mathrm{N}$-added treatments $\left(p<0.001^{* *}, p<0.01^{* *}, p<0.05^{*}\right)$.
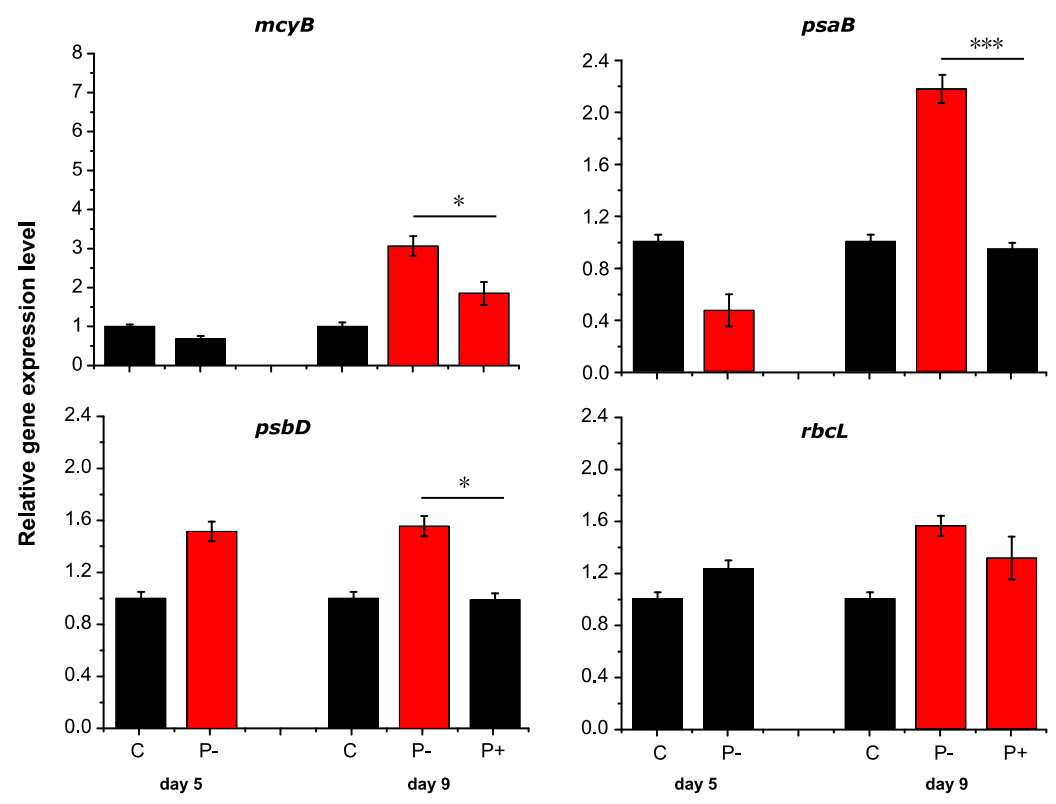

Treatment (P)

Figure 3. Relative transcription levels of target genes in $P$ treatments. Red colors indicate the significant results compared to the control $(p<0.05)$. Significant differences are noted between P-deficient and P-added treatments $\left(p<0.001^{* *}, p<0.01^{* *}, p<0.05^{*}\right)$.

\subsection{Examination of antioxidant systems}

The MDA, SOD and GSH contents of Microcystis cells cultured across all the conditions have been shown in Figure 4. All data were normalized to cell density determined by absorbance at $650 \mathrm{~nm}$. On Day 3, the concentration of MDA (per $10^{6}$ cells) in N-deficient group was lower than the control 
and P-deficient cultures $(p<0.05)$, but the content increased significantly on Day 5 . No significant differences were seen in the concentration of SOD (per $10^{6}$ cells) within the treatments on Day 3, while the concentration was significantly higher in P-deficient group on Day 5. Additionally, the GSH contents (per $10^{6}$ cells) in nutrient deficient treatments were higher than the control (Day 3 and Day 5), with the highest content reaching about $1.75 \mathrm{U} / 10^{6}$ cells.

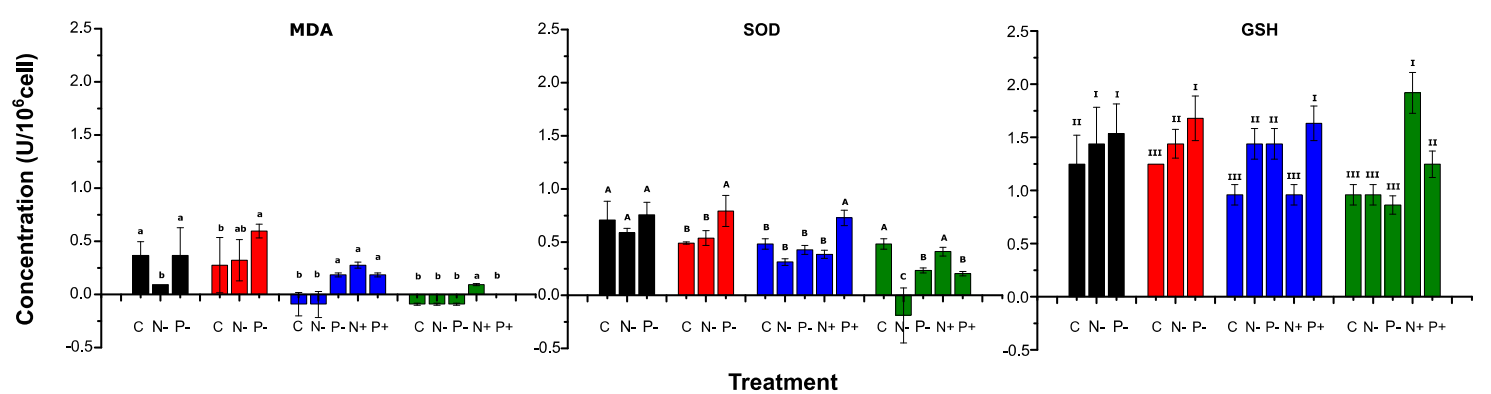

Figure 4. The concentration of Malondialdehyde (MDA), Glutathione (GSH) and Superoxide dismutase (SOD) of M. aeruginosa at each treatment. Different colors represent sampling days: Day 3 (black), Day 5 (red), Day 7 (blue) and Day 9 (green). Same letters indicate observations that are statistically indistinguishable (ANOVA, $p<0.05)$.

The contents of MDA, SOD and GSH changed significantly after nutrients were reintroduced. Specifically, the MDA content declined significantly in most cultures from Day 7, and those in $\mathrm{N}$-deficient cultures even declined to 0 . No significant differences were found in SOD contents among treatments except the P-added group on Day 7, while those in control and $\mathrm{N}$-added treatments were significantly higher than the others on Day 9. The GSH content possessed the highest values in P- (Day 7) and N-added treatments (Day 9), respectively, while the concentration declined in the nutrient deficient groups significantly.

A Pearson's correlation analysis of the correlations between MDA and enzyme activities at all treatments was displayed in Table 1. Specifically, a strong correlation was found between the contents of MDA and SOD, with $p$ value of 0.002 and Pearson's correlation coefficient of 0.7261 . A moderate correlation was seen between MDA and GSH, with Pearson's correlation coefficient of 0.5363 , but the correlation was still significant $(p<0.05)$.

Table 1. Pearson's correlation analysis between MDA and SOD, GSH concentrations at all treatments.

\begin{tabular}{cccc}
\hline Pearson's Correlation Analysis & $\boldsymbol{p}$ Value & $\begin{array}{c}\text { Pearson's } \\
\text { R }\end{array}$ & Adj. R-Square \\
\hline MDA vs. SOD & 0.002 & 0.7261 & 0.4908 \\
MDA vs. GSH & 0.039 & 0.5363 & 0.2328 \\
\hline
\end{tabular}

\section{Discussion}

There have been debates for years about the correlation between nutrient loading and harmful algae blooms and toxin productions. In this paper, we addressed the transcriptional responses of toxin formation gene and key photosynthesis genes to different nutrient loading treatments in Microcystis aeruginosa FACHB-905 using RT-qPCR. Our observations revealed that nutrient-deficient conditions favored the transcription of mcy gene and $\mathrm{N}$ seems more likely than $\mathrm{P}$ as a limiting factor in toxin production of Microsystis. Moreover, Microcystis cells presented high cell density and photosynthetic activities in P-deficient conditions, indicated by the high transcription levels of key photosynthesis genes, while cells in $\mathrm{N}$-deficient conditions turned to show an adaptive regulation after a few day incubation and a long term survival eventually. The increase of antioxidant enzyme contents under an excess of ROS caused by nutrient stress suggested the ability of Microcystis cells 
in the regulation of redox system balance under stress. We consider these results in terms of the transcriptional and physiological response of $M$. aeruginosa to nutrient loading and within the context of providing more insight into naturally occurring Microcystis blooms and toxin regulation.

Previous reports have shown conflicting observations on the regulation of MC by the availability of $\mathrm{N}$. An overall increase of MC production was seen with an increasing $\mathrm{N}$ availability in M. aeruginosa [25], while others demonstrated an increase of MC production under $\mathrm{N}$-deficient conditions [26,27]. The fact that the global nitrogen regulator NtcA binding site locates in the promoter of $m c y$ genes indicates the transcription of mcy gene cluster may itself be under direct control of $\mathrm{N}$ availability [23,26]. Our results are generally in accord with the hypothesis that low $\mathrm{N}$ concentration results in a high transcription of toxin genes, confirmed by a significant increase of $m c y B$ transcripts in $\mathrm{N}$-deficient condition and a rapid decrease after $\mathrm{N}$ was added (Figure 2). Lending support to this claim, Ginn et al. [26] reported that transcription of $m c y B$ increased 14-fold in $\mathrm{N}$-limited relative to $\mathrm{N}$-replete treatments. Regarding $\mathrm{P}$, although there have been some studies on the effect of $\mathrm{P}$ availability on the MC production, no conclusive results were found so far. Eldridge et al. [32] reported significant correlations between MC concentrations with total phosphorus (TP) and dissolved inorganic phosphorus (DIP) concentrations in sediment. A steady increase of $m c y D$ transcripts was detected in deficiency of $\mathrm{P}$ with no significant changes under excess phosphate [13]. In this study, 3-fold of $m c y B$ transcripts was found in P-deficient compared to the control. Although the MC content was not measured in this study, the significant high transcription of $m c y B$ in nutrient-deficient treatment suggests that low nutrient concentration is potentially responsible for MC occurrence, and $\mathrm{N}$ is more likely than $\mathrm{P}$ to eventually regulate the toxin production. The addition of $\mathrm{N}$ would be the factor limiting of toxin production, whereas a $\mathrm{N}$ deficiency would allow production to continue in Microcystis.

Photosynthesis is tightly linked to whole cyanobacterial physiology by reciprocal controls [33]. Our results showed significant low transcription of $p s a B, p s b D$ and $r b c L$ in $\mathrm{N}$-deficient condition, indicating the photosynthesis process was inhibited at the first three days (Figure 2). This was in consistence with Harke's report [34], in which case, low N $(75 \mu \mathrm{M}$ nitrate) resulted in significant decrease of transcript abundance of $r b c L$ and $r b c S$. These two genes encode the large (RubisCo) and small subunits of ribulose biphosphate carboxylase in photosynthesis respectively. Besides, a significant lower photosynthetic efficiency and decrease of many genes transcripts relating to photosynthesis were also observed in N-limited cultures in M. aeruginosa LE-3 [34]. In contrast, metabolite profiles for carbon fixation was reported to be enhanced under $\mathrm{N}$ starvation, and photosynthetic efficiency of PSII was significantly enhanced in the $\mathrm{N}$-deficient cultures compared to the control [12]. Significantly large number of transcripts of $r b c L$ and $p s b D$ were found in $\mathrm{N}$-deficient on Day 9 in this study (Figure 2), which might suggest that the transcription profiles of key photosynthesis genes in N-limited condition varied with the culture period. Under N-limited conditions, glycogen granules could be accumulated in cyanobacteria cells [35], which act as an energy and carbon reservoir for a prolonged period of $\mathrm{N}$ limitation and long-term survival [12,36]. In light of this, there is still a possibility for Microcystis blooms under nutrient limitation.

Under P deficiency, Microcystis cultures could display high rate of alkaline phosphatase activity (APA) to enhance the P availability [34,37] and exhibit nearly normal growth for at least seven days [12]. Four genes (phoX, sphX and two pstS genes) correlated with $\mathrm{P}$ acquisition and transport have been observed to be largely increase of transcript abundance in P-limited condition [34]. These coincide with the observation of high transcription levels of photosynthesis genes in P-deficient condition in our study (Figure 3). Such limited condition of P-loading might give an ecological superiority for $M$. aeruginosa over other phytoplankton competitors in freshwater ecosystems. It is interesting to note that the expressions of $p s a B$ and $p s b D$ significantly declined after $\mathrm{P}$ was resupplied (Figure 3 ). Plenty of evidence has been reported that Microcystis was capable of phosphate uptake to form polyphosphate bodies under phosphate-replete conditions $[38,39]$. The synthesis of polyphosphate needs one ATP for extending P-P bond [40], which competes for energy with the photosynthesis of Microcystis and transcripts abundance of photosynthesis genes are likely to decline. Recently, RubisCo 
has been suggested to be the main binding target for MC under oxidative stress conditions [41]. Moreover, $r b c L$ was reported to be repressed by NtcA binding as well, though it is not involved in $\mathrm{N}$ assimilation [42]. Nevertheless, no evident relationship between the $m c y$ and $r b c L$ gene expression has been found in this study.

It is well known that the free radicals content $\left(\mathrm{O}_{2}{ }^{-}, \mathrm{H}_{2} \mathrm{O}_{2}, \mathrm{OH}^{-}\right.$etc.) in phototrophs will increase under environmental stress[30,31], destroying the physicochemical properties of cell membranes [43] and disrupt the physiological activity of Microcystis consequently. The activity pattern of different antioxidant enzymes exhibited specific manners in different nutrient conditions. MDA is the primary product of lipid peroxidation, which reflects the degree of damage of Microcystis cells [44]. Contrary to our expectations, the MDA concentration (per $10^{6}$ cells) in N-deficient cultures were significantly lower than the control on Day 3 (Figure 4). This might be due to $\mathrm{N}$-deficient conditions causing the response to intracellular ROS on GSH level, and that ameliorated the effects of MDA, which was generated at lower extent (Figure 4). This might also suggest that $\mathrm{N}$ limitation did not destroy the integrity of cell membrane, giving more evidences for the hypothesis that Microcystis cells could survive in a prolonged period of $\mathrm{N}$-deficient condition. Many studies confirmed that most antioxidant enzymes activities enhance under stress conditions, like SOD, GSH, peroxidase (POD) and catalase (CAT) $[45,46]$. SOD and GSH act as catalysts in the reaction of $\mathrm{O}_{2}{ }^{-}$(ROS), converting it into the relative low cytotoxic $\mathrm{H}_{2} \mathrm{O}_{2}[47,48]$. CAT can convert $\mathrm{H}_{2} \mathrm{O}_{2}$ into $\mathrm{H}_{2} \mathrm{O}$ and $\mathrm{O}_{2}$, defending against the oxidative damage caused by $\mathrm{H}_{2} \mathrm{O}_{2}$ [46]. Although the activity of CAT was not evaluated in this study, according to the measurements of SOD and GSH, we suspect the activity of CAT might present a similar trend. Significantly high contents of SOD and GSH were found in P-deficient cultures in the first five days (Figure 4), indicating that the antioxidant system was initiated to remove the excess free radical caused by the nutrient stress, but the enzymes consumed on Day 9. After the resupply of nutrients, the SOD and GSH contents increased significantly in nutrient-added treatments compared to nutrient-deficient cultures, which reflected the continuous free radical scavenging ability of cells. A strong correlation was seen between the MDA and enzyme activities (Table 1), indicating the robust effort of rebalance of the oxidation and antioxidant defense system in Microcystis cells.

It is also important to address the limitations of this study. The physico-chemical conditions were not measured in these incubated cultures, like the $\mathrm{N}$ and $\mathrm{P}$ concentrations at each time point. It would be interesting to explore whether nutrient-deficient cultures actually faced increased $\mathrm{P}$ or $\mathrm{N}$ concentration due to the partial cell lysis, which might give more indications on the physiological response of Microcystis examined in the current study. Additionally, the measurement of MC concentration and congeners should be involved, as well as the transcription of other toxin genes, to provide more insight into the regulation of toxin formation under different nutrient conditions.

The transcription profile of target genes associated with toxin formation and photosynthesis in Microcystis aeruginosa FACHB-905 grown in nutrient deficient and replete is an important step toward providing a broader knowledge of this toxic, bloom-forming cyanobacterium, providing proxies to ascertain cell physiology in situ as well as new insight in ongoing efforts to manage harmful algae bloom events. Future proteomic studies will help to clarify transcriptional profiles observed in this work, along with transcriptomic analyses for a comprehensive understanding of Microcystis physiology and MC synthesis.

\section{Materials and Methods}

\subsection{Strain and Culture Conditions}

Microcystis aeruginosa (FACHB-905) cultures were grown in standard BG11 medium [49] adjusted to $\mathrm{pH}$ 8.5. A factorial design was used to investigate the effects of $\mathrm{N}$ and $\mathrm{P}$ on the target gene expression and antioxidant enzyme activities in M. aeruginosa. Cells in exponential growth phase were collected by centrifugation at $6000 \mathrm{~g}$ for $10 \mathrm{~min}$, and the pelleted cells were washed three times with $\mathrm{N}$ - and P-free BG11 medium prior to the onset of the experiments, respectively. Subsequently, cultures were 
inoculated in $\mathrm{N}$ - and P-free medium at initial cell densities of $\sim 3.87 \times 10^{6} / \mathrm{mL}$ under a 12:12 light/dark cycle at $25{ }^{\circ} \mathrm{C}$ under the illumination of $40 \mu \mathrm{mol}$ photons $\mathrm{m}^{-2} \mathrm{~s}^{-1}$. After a five-day treatment, $\mathrm{NaNO}_{3}$ (17.60 mM-N) and $\mathrm{K}_{2} \mathrm{HPO}_{4}(0.03 \mathrm{mM}-\mathrm{P})$ were supplied as the $\mathrm{N}$ and $\mathrm{P}$ sources for half of the $\mathrm{N}$ - and P-deficient treatments, respectively. The concentrations were in accord with the $\mathrm{N}$ and P in BG11 growth medium. The other half of the cells were continually grown in N- and P-free medium until the end of sampling. Cells grown in standard BG11 medium were considered as the control. For each treatment, three independent biological replicates were established. Cell abundance was measured daily according to the previous method [8]. Samples in exponential growth phase were collected twice for RNA extraction (Day 5 and Day 9) and every other day for M. aeruginosa cells enzyme activity investigation.

\subsection{RNA Extraction and Transcript Analysis}

M. aeruginosa cells were suspended in Trizol lysis buffer (Total RNA Extractor, Sangon Biotech, Shanghai, China) for RNA extraction. Two extractions with chloroform were followed by two extractions with isopropyl alcohol. RNA was then ethanol precipitated using standard methods [50] and resuspended in RNase-free water. Contaminating genomic DNA was removed with a Turbo DNA-free kit (Ambion, Carlsbad, CA, USA). Samples were considered DNA free if no bands were visible in an agarose gel after 30 cycles of PCR amplification using 27F and 1522R primers [51]. RNA was further quantified by NanoDrop spectrophotometer and the quality and concentration for a selection of samples was verified using Agilent 2100 Bioanalyzer. A total amount of $500 \mathrm{ng}$ RNA was used for the real-time reverse transcription quantitative polymerase chain reaction (RT-qPCR). The cDNA was generated using the AMV First Strand cDNA Synthesis Kit (Sangon Biotech, Shanghai, China) following the manufacturer's protocol. cDNA samples were stored at $-20^{\circ} \mathrm{C}$ before running RT-qPCR.

\subsection{Relative RT-qPCR Assay}

The primers of target genes were designed using the Primer Premier 5.0 for real-time RT-qPCR (Table 2). $16 \mathrm{~S}$ rRNA was used as the housekeeping gene. Copy number of target genes for each sample was quantified by RT-qPCR using a ABI Stepone plus PCR system (Bio-Rad, Hercules, CA, USA).

Table 2. Primers for RT-qPCR in this study

\begin{tabular}{|c|c|c|c|}
\hline Primer & Nucleotide Sequence $\left(5^{\prime}\right.$ to $\left.3^{\prime}\right)$ & Amplification Size (bp) & Reference \\
\hline $16 S \mathrm{~F}$ & GGACGGGTGAGTAACGCGTA & \multirow{2}{*}{74} & \multirow{2}{*}[52]{} \\
\hline $16 S \mathrm{R}$ & CCCATTGCGGAAAATTCCCC & & \\
\hline$m c y B \mathrm{~F}$ & CCTACCGAGCGCTTGGG & \multirow[b]{2}{*}{77} & \multirow{2}{*}{ This study } \\
\hline$m c y B \mathrm{R}$ & GAAAATCCCCAAAGATTCCTGAGT & & \\
\hline psaB F & CGGTGACTGGGGTGTGTATG & \multirow{2}{*}{119} & \multirow{2}{*}{ This study } \\
\hline$p s a B \mathrm{R}$ & ACTCGGTTTGGGGATGGA & & \\
\hline$p s b D \mathrm{~F}$ & TCTTCGGCATCGCTTTCTC & \multirow{2}{*}{90} & \multirow{2}{*}{ This study } \\
\hline$p s b D \mathrm{R}$ & CACCCACAGCACTCATCCA & & \\
\hline$r b c L F$ & CGTTTCCCCGTCGCTTT & \multirow{2}{*}{122} & \multirow{2}{*}{ This study } \\
\hline$r b c L \mathrm{R}$ & CCGAGTTTGGGTTTGATGGT & & \\
\hline
\end{tabular}

Reaction mixtures were formulated using SybrGreen qPCR Master Mix (Bio Basic Inc., Toronto, $\mathrm{ON}$, Canada). Thermal cycling conditions were: $95^{\circ} \mathrm{C}$ for $3 \mathrm{~min}, 40$ cycles of 3-step amplification of $7 \mathrm{~s}$ at $95{ }^{\circ} \mathrm{C}, 10 \mathrm{~s}$ at $57^{\circ} \mathrm{C}$ and $15 \mathrm{~s}$ at $72{ }^{\circ} \mathrm{C}$. Melting curves were examined to detect potential non-specific amplification. Amplification efficiency of each primer set was calculated; amplification efficiency between $90 \%$ and $110 \%$ was considered acceptable. All qPCR reactions were conducted in triplicate and the experiments were repeated at least twice. The transcript levels of each target gene were normalized by $16 S$ rRNA transcripts and then calculated relative to control using the 
$2^{-\Delta \Delta \mathrm{Ct}}$. According to Plaffl [53], the $\Delta \Delta \mathrm{Ct}$ value of each treatment was calculated based on the following formula:

$$
\Delta \Delta \mathrm{Ct}=\left(C_{t} \text { target genes }-C_{t} 16 S\right)_{\text {test }}-\left(C_{t} \text { target genes }-C_{t} 16 S\right)_{\text {control }}
$$

\subsection{Enzyme Extraction and Assays}

M. aeruginosa cultures of each treatment $(60 \mathrm{~mL})$ were collected by a Whatman GF/C filter $(0.22-\mu \mathrm{m}$ nominal pore-size) for enzyme investigation. Liquid nitrogen grinding method was used for sample extraction and $6 \mathrm{~mL}$ of phosphate buffer saline (PBS, $0.05 \mathrm{M}, \mathrm{pH} 7.8$ ) was used for each sample [54,55]. After centrifugation at $6000 \mathrm{~g}$ for $15 \mathrm{~min}$, the supernatant was assayed for enzyme activity using a spectrophotometer (UV-2100, UNICO, Shanghai, China). Commercially available kits (MDA assay kit, T-SOD assay kit, and GSH assay kit; Nanjing Jiancheng Bioengineering Institute, Nanjing, Jiangsu Province, China) were used to determine the lipid peroxidation and antioxidant enzyme concentrations. Specifically, the thiobarbituric acid [56], xanthine oxidase [57] and 5,5'-dithiobis-2-nitrobenzoic acid [58] were used to form the colored complex of MDA, SOD and GSH respectively, and spectrophotometric analysis were used to determine the absorbance of the complex at 532, 550 and $420 \mathrm{~nm}$, respectively. The concentrations were then calculated according to the formulas described by the supplier's instructions. The MDA and enzyme concentrations were normalized to cell number before statistical analysis.

\subsection{Statistical Analysis}

All experiments were performed with three independent replicates and the data were reported as the mean \pm standard deviation. One-way analysis of variance (ANOVA) was carried out to test the differences in the data of cell number, transcripts and enzyme concentrations $(p<0.05)$ between treatments using the Origin 8.0 (OriginLab, Northampton, MA, USA). Post-hoc comparisons of significant impacts were conducted with Tukey's multiple comparison tests. T-test were conducted to examine the significant differences in transcripts between nutrient-deficient and nutrient-added treatments. A Pearson's correlation analysis was conducted to determine the correlations between MDA and enzyme activities $(p<0.05)$.

Acknowledgments: This study was supported jointly by the Key Program of National Key R\&D Plan (2016YFC0502700), and the Major Program of National Social Science Foundation of China (14ZDB140).

Author Contributions: G.P. and Z.F. conceived and designed the experiments; G.P. performed the experiments; G.P. analyzed the data; X.W. contributed reagents/materials/analysis tools; and G.P. and S.L. wrote the paper.

Conflicts of Interest: The authors declare no conflict of interest.

\section{References}

1. Davis, T.W.; Berry, D.L.; Boyer, G.L.; Gobler, C.J. The effects of temperature and nutrients on the growth and dynamics of toxic and non-toxic strains of Microcystis during cyanobacteria blooms. Harmful Algae 2009, 8, 715-725. [CrossRef]

2. Paerl, H.W.; Huisman, J. Blooms Like It Hot. Science 2008, 320, 57-58. [CrossRef] [PubMed]

3. Fleming, L.E.; Rivero, C.; Burns, J.; Williams, C.; Bean, J.A.; Shea, K.A.; Stinn, J. Blue green algal (cyanobacterial) toxins, surface drinking water, and liver cancer in Florida. Harmful Algae 2002, 1, 157-168. [CrossRef]

4. Peng, G.; Fan, Z.; Wang, X.; Sui, X.; Chen, C. Photodegradation of microcystin-LR catalyzed by metal phthalocyanines immobilized on $\mathrm{TiO}_{2}-\mathrm{SiO}_{2}$ under visible-light irradiation. Water Sci. Technol. 2015, 72, 1824-1831. [CrossRef] [PubMed]

5. Chia, M.A.; Cordeiro-Araújo, M.K.; Lorenzi, A.S.; Bittencourt-Oliveira, M.d.C. Cylindrospermopsin induced changes in growth, toxin production and antioxidant response of Acutodesmus acuminatus and Microcystis aeruginosa under differing light and nitrogen conditions. Ecotoxicology and Environmental Safety 2017, 142, 189-199. [CrossRef] [PubMed] 
6. Rzymski, P.; Poniedziałek, B.; Kokociński, M.; Jurczak, T.; Lipski, D.; Wiktorowicz, K. Interspecific allelopathy in cyanobacteria: Cylindrospermopsin and Cylindrospermopsis raciborskii effect on the growth and metabolism of Microcystis aeruginosa. Harmful Algae 2014, 35, 1-8. [CrossRef]

7. Belisle, B.S.; Steffen, M.M.; Pound, H.L.; Watson, S.B.; Debruyn, J.M.; Bourbonniere, R.A.; Boyer, G.L.; Wilhelm, S.W. Urea in Lake Erie: Organic nutrient sources as potentially important drivers of phytoplankton biomass. J. Great Lakes Res. 2016, 42, 599-607. [CrossRef]

8. Peng, G.; Fan, Z.; Wang, X.; Chen, C. Photosynthetic response to nitrogen source and different ratios of nitrogen and phosphorus in toxic cyanobacteria, Microcystis aeruginosa FACHB-905. J. Limnol. 2016, 75, 560-570. [CrossRef]

9. Steffen, M.M.; Dearth, S.P.; Dill, B.D.; Li, Z.; Larsen, K.M.; Campagna, S.R.; Wilhelm, S.W. Nutrients drive transcriptional changes that maintain metabolic homeostasis but alter genome architecture in Microcystis. The ISME J. 2014, 8, 2080-2092. [CrossRef] [PubMed]

10. Smith, V.H. Low nitrogen to phosphorus ratios favor dominance by blue-green algae in lake phytoplankton. Science 1983, 221, 669-671. [CrossRef] [PubMed]

11. Likens, G.E.; Bartsch, A.F.; Lauff, G.H.; Hobbie, J.E. Nutrients and Eutrophication. Science 1971, $172,873-874$. [CrossRef] [PubMed]

12. Yue, D.; Peng, Y.; Yin, Q.; Xiao, L. Proteomic analysis of Microcystis aeruginosa in response to nitrogen and phosphorus starvation. J. Appl. Phycol. 2015, 27, 1-10. [CrossRef]

13. Kuniyoshi, T.M.; Sevilla, E.; Bes, M.T.; Fillat, M.F.; Peleato, M.L. Phosphate deficiency (N/P 40:1) induces mcyD transcription and microcystin synthesis in Microcystis aeruginosa PCC7806. Plant Physiol. Biochem. 2013, 65, 120-124. [CrossRef] [PubMed]

14. Oh, H.M.; Lee, S.J.; Jang, M.H.; Yoon, B.D. Microcystin production by Microcystis aeruginosa in a phosphorus-limited chemostat. Appl. Environ. Microbiol. 2000, 66, 176-179. [CrossRef] [PubMed]

15. Downing, T.G.; Sember, C.S.; Gehringer, M.M.; Leukes, W. Medium N:P ratios and specific growth rate comodulate microcystin and protein content in Microcystis aeruginosa PCC7806 and M. aeruginosa UV027. Microb. Ecol. 2005, 49, 468-473. [CrossRef] [PubMed]

16. Lee, S.J.; Jang, M.H.; Kim, H.S.; Yoon, B.D.; Oh, H.M. Variation of microcystin content of Microcystis aeruginosa relative to medium N:P ratio and growth stage. Eur. J. Appl. Microbiol. 2000, 89, 323-329. [CrossRef] [PubMed]

17. Utkilen, H.; Gjølme, N. Iron-stimulated toxin production in Microcystis aeruginosa. Appl. Environ. Microbiol. 1995, 61, 797-800. [PubMed]

18. Jähnichen, S.; Long, B.M.; Petzoldt, T. Microcystin production by Microcystis aeruginosa Direct regulation by multiple environmental factors. Harmful Algae 2011, 12, 95-104. [CrossRef]

19. Watanabe, M.F.; Oishi, S. Effects of environmental factors on toxicity of a cyanobacterium (Microcystis aeruginosa) under culture conditions. Appl. Environ. Microbiol. 1985, 49, 1342-1344. [PubMed]

20. Orr, P.T.; Jones, G.J. Relationship between microcystin production and cell division rates in nitrogen-limited Microcystis aeruginosa cultures. Limnol. Oceanogr. 1998, 43, 1604-1614. [CrossRef]

21. Sevilla, E.; Martinluna, B.; Vela, L.; Bes, M.T.; Peleato, M.L.; Fillat, M.F. Microcystin-LR synthesis as response to nitrogen: transcriptional analysis of the mcyD gene in Microcystis aeruginosa PCC7806. Ecotoxicology 2010, 19, 1167-1173. [CrossRef] [PubMed]

22. Gobler, C.J.; Davis, T.W.; Coyne, K.J.; Boyer, G.L. Interactive influences of nutrient loading, zooplankton grazing, and microcystin synthetase gene expression on cyanobacterial bloom dynamics in a eutrophic New York lake. Harmful Algae 2007, 6, 119-133. [CrossRef]

23. Flores, E.; Herrero, A. Nitrogen assimilation and nitrogen control in cyanobacteria. Biochem. Soc. Trans. 2005, 33, 164-167. [CrossRef] [PubMed]

24. Horst, G.P.; Sarnelle, O.; White, J.D.; Hamilton, S.K.; Kaul, R.R.B.; Bressie, J.D. Nitrogen availability increases the toxin quota of a harmful cyanobacterium, Microcystis aeruginosa. Water Res. 2014, 54, 188-198. [CrossRef] [PubMed]

25. Downing, T.; Meyer, C.; Gehringer, M.; Van de Venter, M. Microcystin content of Microcystis aeruginosa is modulated by nitrogen uptake rate relative to specific growth rate or carbon fixation rate. Environ. Toxicol. 2005, 20, 257-262. [CrossRef] [PubMed]

26. Ginn, H.; Pearson, L.; Neilan, B. NtcA from Microcystis aeruginosa PCC 7806 is autoregulatory and binds to the microcystin promoter. Appl. Environ. Microbiol. 2010, 76, 4362-4368. [CrossRef] [PubMed] 
27. Long, B.M.; Jones, G.J.; Orr, P.T. Cellular microcystin content in N-limited Microcystis aeruginosa can be predicted from growth rate. Appl. Environ. Microbiol. 2001, 67, 278-283. [CrossRef] [PubMed]

28. Pimentel, J.S.M.; Giani, A. Microcystin production and regulation under nutrient stress conditions in toxic Microcystis strains. Appl. Environ. Microbiol. 2014, 80, 5836-5843. [CrossRef] [PubMed]

29. Asada, K. Chloroplasts: Formation of active oxygen and its scavenging. Methods Enzymol. 1984, 105, 422-429.

30. Kebeish, R.; El-Ayouty, Y.; Husain, A. Effect of copper on growth, bioactive metabolites, antioxidant enzymes and photosynthesis-related gene transcription in Chlorella vulgaris. World J. Biol. Biol. Sci. 2014, 2, 34-43.

31. Hu, Z.; Liu, Y.; Li, D.; Dauta, A. Growth and antioxidant system of the cyanobacterium Synechococcus elongatus in response to microcystin-RR. Hydrobiologia 2005, 534, 23-29. [CrossRef]

32. Eldridge, S.L.C.; Wood, T.M.; Echols, K.R.; Topping, B.R. Microcystins, nutrient dynamics, and other environmental factors during blooms of non-microcystin-producing Aphanizomenon flos-aquae in Upper Klamath Lake, Oregon, 2009. Lake Reservoir Manage. 2013, 29, 68-81. [CrossRef]

33. Paul, M.J.; Foyer, C.H. Sink regulation of photosynthesis. J. Exp. Bot. 2001, 52, 1383-1400. [CrossRef] [PubMed]

34. Harke, M.J.; Gobler, C.J. Global transcriptional responses of the toxic cyanobacterium, Microcystis aeruginosa, to nitrogen stress, phosphorus stress, and growth on organic matter. PLoS ONE 2013, 8, e69834. [CrossRef] [PubMed]

35. Schwarz, R.; Forchhammer, K. Acclimation of unicellular cyanobacteria to macronutrient deficiency: emergence of a complex network of cellular responses. Microbiology 2005, 151, 2503-2514. [CrossRef] [PubMed]

36. Allen, M.M. Cyanobacterial Cell Inclusions. Annu. Rev. Microbiol. 1984, 38, 1-25. [CrossRef] [PubMed]

37. Ding, Y.; Qin, B.; Xu, H.; Wang, X. Effects of sediment and turbulence on alkaline phosphatase activity and photosynthetic activity of phytoplankton in the shallow hyper-eutrophic Lake Taihu, China. Environ. Sci. Pollut. Res. Int. 2016, 23, 1-11. [CrossRef] [PubMed]

38. Baldia, S.; Evangelista, A.; Aralar, E.; Santiago, A. Nitrogen and phosphorus utilization in the cyanobacterium Microcystis aeruginosa isolated from Laguna de Bay, Philippines. J. Appl. Phycol. 2007, 19, 607-613. [CrossRef]

39. Jacobson, L.; Halmann, M. Polyphosphate metabolism in the blue-green alga Microcystis aeruginosa. J. Plankton Res. 1982, 4, 481-488. [CrossRef]

40. Shi, X.; Yang, L.; Niu, X.; Xiao, L.; Kong, Z.; Qin, B.; Gao, G. Intracellular phosphorus metabolism of Microcystis aeruginosa under various redox potential in darkness. Microbiol. Res. 2003, 158, 345-352. [CrossRef] [PubMed]

41. Zilliges, Y.; Kehr, J.-C.; Meissner, S.; Ishida, K.; Mikkat, S.; Hagemann, M.; Kaplan, A.; Börner, T.; Dittmann, E. The cyanobacterial hepatotoxin microcystin binds to proteins and increases the fitness of Microcystis under oxidative stress conditions. PLoS ONE 2011, 6, e17615. [CrossRef] [PubMed]

42. Ramasubramanian, T.; Wei, T.F.; Oldham, A.K.; Golden, J.W. Transcription of the Anabaena sp. strain PCC 7120 NtcA gene: multiple transcripts and NtcA binding. J. Bacteriol. 1996, 178, 922-926. [CrossRef] [PubMed]

43. Huang, H.; Xiao, X.; Ghadouani, A.; Wu, J.; Nie, Z.; Peng, C.; Xu, X.; Shi, J. Effects of natural flavonoids on photosynthetic activity and cell integrity in Microcystis aeruginosa. Toxins 2015, 7, 66-80. [CrossRef] [PubMed]

44. Chen, J.; Qian, Y.; Li, H.; Cheng, Y.; Zhao, M. The reduced bioavailability of copper by nano-TiO 2 attenuates the toxicity to Microcystis aeruginosa. Environ. Sci. Pollut. Res. Int. 2015, 1-8. [CrossRef] [PubMed]

45. Liu, Y.; Guan, Y.; Gao, B.; Yue, Q. Antioxidant responses and degradation of two antibiotic contaminants in Microcystis aeruginosa. Ecotoxicol. Environ. Saf. 2012, 86, 23-30. [CrossRef] [PubMed]

46. Wan, J.; Guo, P.; Peng, X.; Wen, K. Effect of erythromycin exposure on the growth, antioxidant system and photosynthesis of Microcystis flos-aquae. J. Hazard. Mater. 2015, 283, 778-786. [CrossRef] [PubMed]

47. Hu, M.; Wu, F.; Yuan, M.; Li, Q.; Gu, Y.; Wang, Y.; Liu, Q. Antioxidant responses of triangle sail mussel hyriopsis cumingii exposed to harmful algae Microcystis aeruginosa and hypoxia. Chemosphere 2015, 139, 541-549. [CrossRef] [PubMed]

48. Liu, Y.; Chen, S.; Zhang, J.; Gao, B. Nitrogen-regulated interactions between Microcystis aeruginosa and spiramycin contaminant. Water Air Soil Pollut. 2015, 226, 1-11. [CrossRef]

49. Rippka, R.; Deruelles, J.; Waterbury, J.B.; Herdman, M.; Stanier, R.Y. Generic assignments, strain histories and properties of pure cultures of cyanobacteria. Microbiology 1979, 111, 1-61. [CrossRef]

50. Sambrook, J.; Russell, D. Molecular Cloning: A Laboratory Manual (3-Volume Set). Immunol. 2001, 49, 895-909. 
51. Edwards, U.; Rogall, T.; Blöcker, H.; Emde, M.; Böttger, E.C. Isolation and direct complete nucleotide determination of entire genes. Characterization of a gene coding for 16S ribosomal RNA. Nucleic Acids Res. 1989, 17, 7843-7853. [CrossRef] [PubMed]

52. Wu, L.; Wu, H.; Chen, L.; Xie, S.; Zang, H.; Borriss, R.; Gao, X. Bacilysin from Bacillus amyloliquefaciens FZB42 has specific bactericidal activity against harmful algal bloom species. Appl. Environ. Microbiol. 2014, 80, 7512-7520. [CrossRef] [PubMed]

53. Pfaffl, M.W. A new mathematical model for relative quantification in real-time RT-PCR. Nucleic Acids Res. 2001, 29, e45. [CrossRef] [PubMed]

54. Ni, L.; Jie, X.; Wang, P.; Li, S.; Wang, G.; Li, Y.; Li, Y.; Acharya, K. Effect of linoleic acid sustained-release microspheres on Microcystis aeruginosa antioxidant enzymes activity and microcystins production and release. Chemosphere 2015, 121, 110-116. [CrossRef] [PubMed]

55. Wang, J.; Xie, P. Antioxidant enzyme activities of Microcystis aeruginosa in response to nonylphenols and degradation of nonylphenols by M. aeruginosa. Environ. Geochem. Health. 2007, 29, 375-383. [CrossRef] [PubMed]

56. Placer, Z.A.; Cushman, L.L.; Johnson, B.C. Estimation of product of lipid peroxidation (malonyl dialdehyde) in biochemical systems. Anal. Biochem. 1966, 16, 359-364. [CrossRef]

57. Winterbourn, C.C.; Hawkins, R.E.; Brian, M.; Carrell, R. The estimation of red cell superoxide dismutase activity. J. Lab. Clin. Med. 1975, 85, 337-341. [PubMed]

58. Hafeman, D.; Sunde, R.; Hoekstra, W. Effect of dietary selenium on erythrocyte and liver glutathione peroxidase in the rat. J. Nutr. 1974, 104, 580-587. [PubMed]

(C) 2017 by the authors. Licensee MDPI, Basel, Switzerland. This article is an open access article distributed under the terms and conditions of the Creative Commons Attribution (CC BY) license (http:/ / creativecommons.org/licenses/by/4.0/). 